Life Science 10 (1) (2021)

Life Science

http://journal.unnes.ac.id/sju/index.php/LifeSci

\title{
Pertumbuhan Kecambah Kentang (Solanum tuberosum L.) secara In Vitro pada Konsentrasi NaClO dan Waktu Sterilisasi yang Berbeda
}

\author{
Khoirin Nida, Masrukhatul Luaeliyah, Yulita Nurchayati, Munifatul Izzati, Nintya Setiari ${ }^{\bowtie}$
}

Departemen Biologi, Fakultas Sains dan Matematika, Universitas Diponegoro Semarang, Indonesia

\section{Info Artikel}

Diterima: 1 Maret 2021

Disetujui: 30 Maret 2021

Dipublikasikan: 15 April 2021

\section{Keywords:}

Sprouts; potatoes; in vitro culture;

$\mathrm{NaClO}$; growth; sterilization

Kecambah; kentang; kultur in vitro;

$\mathrm{NaClO}$; pertumbuhan; sterilisasi

\begin{abstract}
Potato (Solanum tuberosum L.) have been cultivated with tubers. One alternative to the propagation potatoes can be done with seeds that are germinated in vitro. The factors that influence the germination potato seeds are the concentration of sterilant and time of sterilization. The purpose of this study was determine the proper sterilant concentration and sterilization time to increase growth in the optin percentage of germination and potato sprouts. The method used is in vitro culture with differ concentrations and time treatment. This study used explants of potato seeds which were sterilized with concentration of $15 \%$ and $20 \%, 1$ and 3 minutes of sterilization. The design used a completely randomiz design $2 \times 2$ factorial. The factor are sterilant concentration and sterilization time. The parameters obsen were germination time, plant height, number of leaves and roots. The results showed that ster concentration did not affect of germination time but affected the germination. A $15 \%$ concentrati indicates that germination occurs rapidly, while a $20 \%$ concentration inhibits germination. A 1 concentration results in an optimal number of leaves and plant height. The higher the concentration sterile, tends to inhibit the growth of roots and leaves.
\end{abstract}

\begin{abstract}
Abstrak
Tanaman kentang (Solanum tuberosum L.) selama ini dibudidayakan dengan umbi. Salah satu alternatif perbanyakan kentang dapat dilakukan dengan biji yang dikecambahkan secara in vitro. Faktor yang mempengaruhi perkecambahan biji kentang adalah konsentrasi sterilan dan waktu sterilisasi. Tujuan penelitian ini adalah mengetahui konsentrasi sterilan (yang mengandung zat aktif $5,25 \% \mathrm{NaClO}$ ) dan waktu sterilisasi yang tepat untuk meningkatkan persentase perkecambahan dan pertumbuhan kecambah kentang. Metode yang digunakan adalah kultur in vitro biji kentang dengan perlakuan konsentrasi sterilan dan waktu sterilisasi yang berbeda. Penelitian ini menggunakan eksplan biji kentang yang dilakukan sterilisasi dengan konsentrasi sterilan $15 \%$ dan $20 \%$ dan waktu sterilisasi 1 menit dan 3 menit. Desain penelitian ini menggunakan Rancangan Acak Lengkap (RAL) pola faktorial $2 \times 2$. Faktor pertama adalah konsentrasi sterilan dan faktor kedua adalah waktu sterilisasi. Parameter yang diamati adalah waktu perkecambahan, tinggi tanaman, jumlah daun, dan jumlah akar. Hasil penelitian menunjukkan bahwa konsentrasi sterilan tidak berpengaruh terhadap waktu perkecambahan dan pertumbuhan kecambah. Konsentrasi sterilan $15 \%$ menyebabkan waktu perkecambahan cenderung lebih cepat dan konsentrasi sterilan $20 \%$ cenderung menghambat pertumbuhan kecambah.
\end{abstract}




\section{PENDAHULUAN}

Kentang (Solanum tuberosum L.) menjadi salah satu komoditas pendukung ketahanan pangan, namun hingga saat ini produktivitasnya masih rendah. Selama ini perbanyakan kentang dilakukan dengan menggunakan umbi, sehingga biji kentang tidak banyak digunakan untuk perbanyakan. Oleh karena itu biji kentang dapat digunakan menjadi salah satu alternatif perbanyakan dengan teknik kultur in vitro. Sterilisasi eksplan merupakan faktor penting yang menentukan keberhasilan kultur in vitro. Faktor yang menentukan keberhasilan proses sterilisasi adalah konsentrasi sterilan dan lama sterilisasi. Sterilisasi merupakan proses penghancuran atau pemusnahan semua kontaminan. Saat melakukan sterilisasi selain untuk mendapatkan eksplan yang steril juga mendapatkan jaringan eksplan yang tidak rusak akibat tingginya konsentrasi desinfektan, sehingga sterilisasi eksplan menentukan keberhasilan kultur in vitro (Pancaningtyas \& Ismayadi, 2011). Salah satu jenis sterilan yang sering digunakan yaitu natrium hipoklorit $(\mathrm{NaClO})$. Natrium hipoklorit merupakan senyawa kimia yang digunakan sebagai desinfektan karena dapat melepaskan klorin yang dapat membunuh mikroorganisme.

Perkecambahan adalah proses kompleks di mana biji harus cepat pulih secara fisik dari pengeringan, melanjutkan intensitas metabolisme yang berkelanjutan, menyelesaikan peristiwa seluler penting untuk memungkinkan embrio muncul, dan mempersiapkan pertumbuhan biji berikutnya. Proses ini juga disebut sebagai tahap yang mengawali terbentuknya individu baru. Perkecambahan diawali dengan proses imbibisi yaitu masuknya air kedalam biji yang menyebabkan kulit pembungkus biji pecah sehingga muncul radikula. Proses ini diikuti dengan adanya pembentukan kembali metabolisme seperti pemulihan integritas kimia dan struktural sel (Nonogaki, et al., 2010)

Kultur jaringan adalah metode untuk menumbuhkan bagian dari suatu tanaman seperti sel, organ, jaringan, dan protoplas. Kelebihan penggunaan kultur jaringan yaitu dapat menghasilkan biji yang bebas penyakit, banyak dan beragam dalam waktu yang singkat dengan penggunaan ruang yang sedikit. Perbanyakan tanaman secara in vitro merupakan suatu metode untuk mengisolasi bagian tanaman yang selanjutnya dapat tumbuh menjadi tanaman yang lengkap. Keberhasilan kultur in vitro dipengaruhi oleh sterilisasi dan kontaminasi. Kultur jaringan merupakan salah satu kegiatan yang dilakukan untuk membuat bagian tanaman (akar, tunas, jaringan tumbuh tanaman) tumbuh menjadi tanaman utuh (sempurna) dalam kondisi aseptik. Oleh karena itu teknik ini merupakan salah satu alternatif bagi perbanyakan tanaman kentang (Molla et al., 2011). Penelitian ini bertujuan untuk menganalisis perkecambahan biji kentang dan pertumbuhan kecambah kentang pada perlakuan konsentrasi sterilan dan waktu sterilisasi yang berbeda.

\section{METODE}

Biji berasal dari buah kentang yang didapat dari perkebunan kentang di Wonosobo. Penelitian ini dilakukan pada bulan Juli 2019-Agustus 2019 di Laboratorium Biologi Struktur dan Fungsi Jurusan 
Biologi Fakultas Sains dan Matematika Universitas Diponegoro Semarang. Penelitian ini menggunakan sterilan komersial (kandungan $\mathrm{NaClO}$ 5,25\%) dengan konsentrasi 15\% dan 20\% dan waktu sterilisasi 1 menit dan 3 menit. Parameter penelitian berupa waktu perkecambahan dan pertumbuhan eksplan dengan parameter pertambahan tinggi tanaman, jumlah daun dan jumlah akar. Rancangan penelitian ini adalah rancangan acak lengkap pola faktorial dengan dua faktor yaitu konsentrasi sterilan dan waktu sterilisasi.

Formulasi media tanam yang digunakan yaitu MS (Murashige and Skoog), sukrosa, zat pemadat dan akuades. Sterilisasi biji dilakukan dengan cara biji diambil dari buah kentang dan dikeringkan selama 2 jam. Biji selanjutnya disterilisasi di dalam LAF dengan cara direndam dalam larutan fungisida selama 7 menit kemudian dibilas dengan akuades steril. Selanjutnya biji direndam dalam larutan $\mathrm{NaClO}$ 15\% (selama 1 menit dan 3 menit) dan larutan $\mathrm{NaClO}$ 20\% (selama 1 menit dan 3 menit) lalu dibilas dengan akuades steril. Biji kemudian direndam dalam alkohol 70\% selama 5 menit selanjutnya dibilas dengan akuades steril hingga bersih.

Biji yang sudah disterilisasi ditanam di media MS tanpa zat pengatur tumbuh. Biji yang telah ditanam diinkubasi pada suhu $18-20^{\circ} \mathrm{C}$, dengan penyinaran lampu 2981 lux setiap hari selama 6 minggu dan diamati setiap hari. Data pengamatan dianalisis dengan analisis sidik ragam (ANOVA) dua arah.

\section{HASIL DAN PEMBAHASAN}

Hasil penelitian perkembangan kentang secara in vitro disajikan dalam Gambar 1. Setelah dianalisis menggunakan uji statistik (ANOVA) dua arah, parameter yang tidak berpengaruh secara signifikan adalah waktu tumbuh kecambah, tinggi tanaman, jumlah daun, dan jumlah akar. Berdasarkan Gambar 1, diketahui bahwa perlakuan konsentrasi sterilan dan waktu sterilisasi tidak mempengaruhi kecepatan waktu tumbuh. Hal ini menunjukkan bahwa sterilisasi dengan $\mathrm{NaClO}$ pada konsentrasi 15\% dan 20\% pada waktu sterilisasi 1 dan 3 menit tidak menyebabkan kerusakan pada benih sehingga tidak menghambat daya perkecambahan eksplan. Biji kentang mengalami perkecambahan paling cepat (27 hari) pada biji yang disterilisasi dengan sterilan konsentrasi 15\% selama 3 menit. Wiguna (2013), menemukan hal sama pada penelitiannya bahwa perlakuan $\mathrm{NaClO}$ pada saat pencucian benih tidak tidak mempengaruhi daya berkecambah benih.

Berdasarkan Gambar 2 diketahui bahwa perkecambahan dimulai dengan keluarnya akar selanjutnya batang mulai memanjang dan mendukung daun pertama. Pada meristem pucuk mulai tumbuh pucuk yang mendukung daun kedua serta batang semakin mamanjang. Perkecambahan adalah proses pertumbuhan embrio dan komponen biji lainya untuk dapat menghasilkan tumbuhan baru. Proses ini dipengaruhi oleh beberapa faktor dalam (tingkat kemasakan, dormansi biji, ukuran biji, dan penghambat perkecambahan) dan faktor luar (air, suhu, dan cahaya). Hal ini sesuai dengan pendapat Wolny et al. (2018) bahwa perkecambahan merupakan tahap awal dari perkembangan tumbuhan berbiji. 


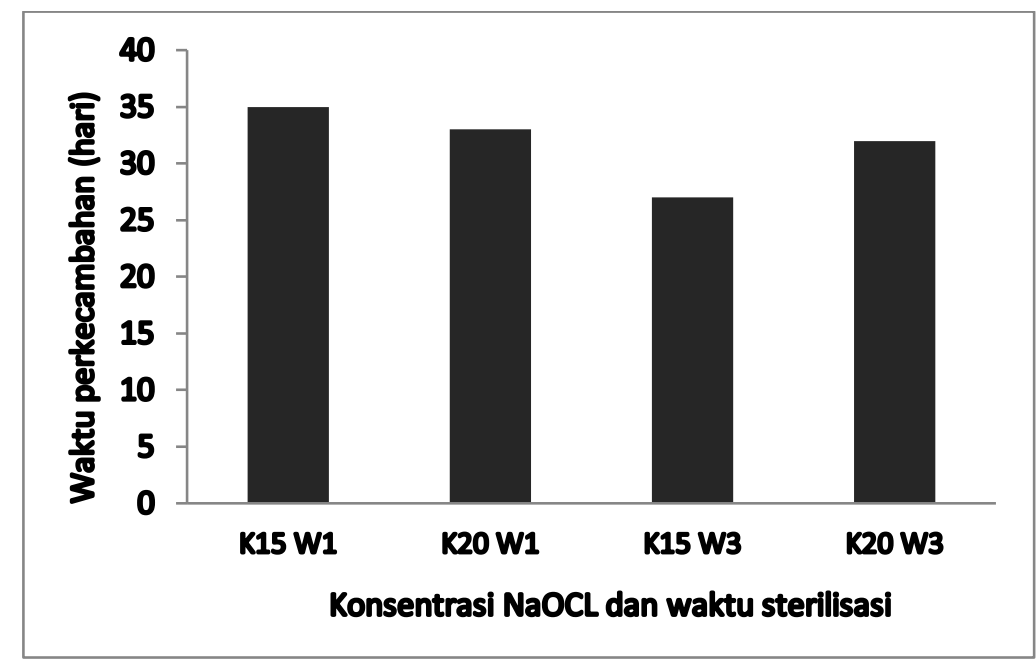

Gambar 1. Histogram rerata waktu perkecambahan (hari) pada media MS dengan konsentrasi NaClO dan waktu perendaman yang berbeda.

Keterangan: $\mathrm{K}_{15} \mathrm{~W}_{1}$ : Konsentrasi $\mathrm{NaClO} 15 \%$ waktu sterilisasi 1 menit $\mathrm{K}_{15} \mathrm{~W}_{3}$ : Konsentrasi $\mathrm{NaClO} 15 \%$ waktu sterilisasi 3 menit $\mathrm{K}_{20} \mathrm{~W}_{1}$ : Konsentrasi $\mathrm{NaClO} 20 \%$ waktu sterilisasi 1 menit $\mathrm{K}_{20} \mathrm{~W}_{3}$ : Konsentrasi $\mathrm{NaClO} 20 \%$ waktu sterilisasi 3 menit

Biji merupakan salah satu organ tumbuhan untuk berkembang biak guna melestarikan jenisnya. Salah satu komponen biji adalah embrio yang nantinya akan berkecambah menjadi tanaman muda jika berada di tempat yang sesuai untuk mendukung perkecambahannya. Faktor lingkungan yang mempengaruhi perkecambahan yaitu air, temperatur, cahaya dan oksigen. Selain faktor lingkungan, faktor utama yang mempengaruhi perkecambahan adalah fisiologis dari biji tersebut. Kerusakan atau gangguan secara fisiologis pada biji dapat menurunkan kemampuan berkecambah biji. Secara morfologis, perkecambahan biji ditandai dengan keluarnya calon akar, batang, dan daun yang nantinya akan tumbuh menjadi akar, batang dan daun yang sempurna. Akar akan menyerap zat hara dari dalam tanah, sedangkan daun akan melakukan proses fotosintesis.

Perkecambahan pada biji ditentukan oleh sifat dari biji, pelemahan endosperma, dan pertumbuhan embrio (Webster et al., 2016). Sebagian besar spesies dari Angiospermae mempunyai embrio diploid yang dikelilingi oleh satu atau lebih lapisan penutup biji. Penutup ini biasanya terdiri dari endosperma triploid dan mantel biji, dimana keduanya berperan dalam mengontrol perkecambahan (Yan et al., 2014). Pertumbuhan sel embrio selama perkecambahan biji tergantung pada kerapatan dinding sel yang ireversibel diikuti oleh pengambilan air karena tekanan turgor yang menurun, dan hal ini menyebabkan perpanjangan embrio dan akhirnya muncul radikula (Steinbrecher \& Metzger, 2017).

Biji kentang berasal dari buah kentang yang berdaging dan berair, oleh karena itu diperlukan pengeringan terlebih dahulu. Menurut Yuniarti et al. (2013), salah satu tahapan awal dalam penanganan benih yaitu kegiatan ekstraksi benih yaitu proses pengeluaran benih dari buah, polong, atau bahan pembungkus benih lainnya sehingga menghasilkan benih yang bersih. Ekstraksi benih dilakukan dengan cara pengeringan, yaitu dengan cara penjemuran di bawah sinar matahari dan dengan menggunakan alat pengeringan. Benih yang tidak bersih identik dengan mudah terkena mikroba dan menyebabkan benih 
mudah busuk dan perkecambahannya lebih lama. Serat yang melekat pada biji tomat mengandung asam absisat yang merupakan zat penghambat perkecambahan dan pertumbuhan benih (Wiguna, 2013). Hal lain disampaikan oleh Surahman (2012), pengeringan benih dilakukan setelah kegiatan ekstraksi dengan tujuan untuk mengurangi kandungan air di dalam benih sebelum dikecambahkan atau disimpan.

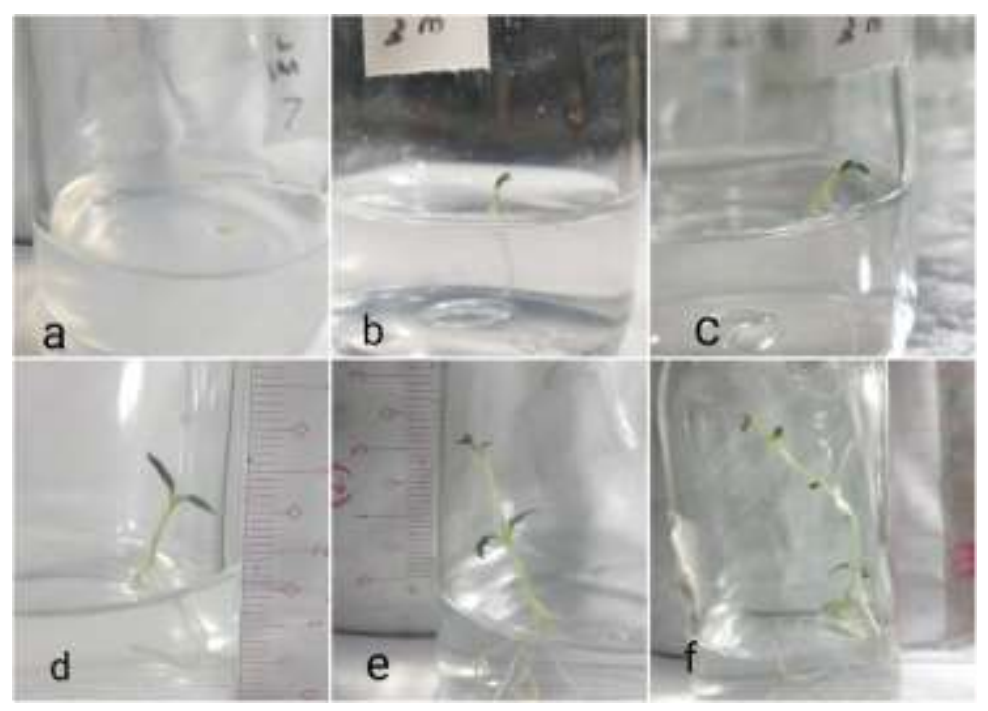

Gambar 2. Proses pekecambahan biji. a. Eksplan setelah ditanam, b. Eksplan berkecambah, c. Eksplan muncul daun pertama, d, e, f. Eksplan tumbuh

Persentase eksplan yang tidak terkontaminasi atau steril pada masing masing perlakuan (Gambar 3) menunjukkan bahwa perlakuan $\mathrm{K}_{15} \mathrm{~W}_{3}$ menunjukan persentase eksplan tidak terkontaminasi tertinggi dan perlakuan $\mathrm{K}_{20} \mathrm{~W}_{3}$ menunjukkan persentase eksplan yang tidak terkontaminasi paling rendah. Hasil analisis uji statistik menunjukkan bahwa konsentrasi sterilan dan waktu sterilisasi tidak mempengaruhi persentase biji tidak kontaminasi sehingga konsentrasi sterilan 15\% dan 20\% efektif untuk meminimalisir terjadinya kontaminasi karena memiliki kandungan $\mathrm{NaClO}$ tinggi. Natrium hipoklorit adalah salah satu senyawa kimia yang digunakan sebagai desinfektan karena dapat melepaskan klorin yang dapat membunuh mikroorganisme seperti bakteri, jamur, dan virus. Menurut Haapasalo et al. (2010), NaClO merupakan agen antimikrobial yang kuat, membunuh hampir seluruh bakteria secara instan melalui kontak langsung.

Tahap sterilisasi dalam kultur in vitro merupakan hal yang sangat penting untuk menentukan keberhasilan kultur in vitro. Fungsi sterilisasi adalah menghilangkan kontaminasi baik dari alat maupun bahan yang digunakan. Menurut Pancaningtyas dan Ismayadi (2011), keberhasilan kultur in vitro ditentukan dari sterilisasi bahan dan alat yang digunakan. Sterilisasi bertujuan agar bahan dan alat bebas dari kontaminasi. Sterilisasi merupakan proses penghancuran atau pemusnahan semua kontaminan. Saat melakukan sterilisasi selain untuk mendapatkan eksplan yang steril juga untuk menjaga agar jaringan eksplan tidak rusak akibat tingginya konsentrasi desinfektan. 


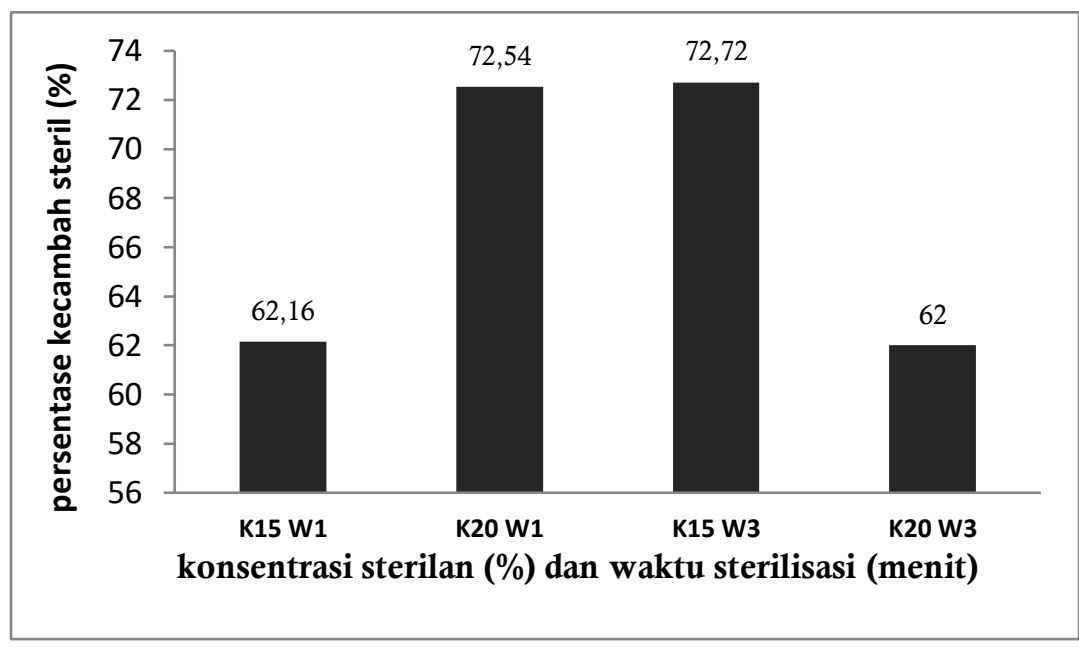

Gambar 3. Histogram rerata persentase kecambah steril pada media MS dengan konsentrasi $\mathrm{NaClO}$ dan waktu perendaman yang berbeda

Sterilisasi yang kurang sempurna kemungkinan besar terjadi pada saat eksplan akan ditanam di dalam botol kultur. Kontaminasi oleh berbagai macam jamur disebabkan oleh sterilisasi yang kurang sempurna sehingga mikroba-mikroba yang ada di dalam maupun di sekitar eksplan berkembang biak di dalam media. Menurut Elfiani (2013), pada saat eksplan akan ditanam, dilakukan sterilisasi bahan tanam dengan menggunakan alkohol 96\% dan larutan Clorox 5,25\%. Apabila perendaman dalam larutan terlalu cepat maka mikroba yang ada kemungkinan masih terbawa di sekitar permukaan eksplan sehingga peristiwa kontaminasi tidak dapat dihindarkan. Kontaminasi eksplan atau media kultur disebabkan oleh jamur dan bakteri. Pada kontaminasi jamur terlihat hifa putih hingga hitam (jenis yang berbeda) muncul pada media ataupun pada bahan tanam, sedangkan kontaminasi oleh bakteri terlihat cairan kental seperti lendir di sekitar bahan tanam maupun media yang merupakan kumpulan massa bakteri. Kontaminasi yang terjadi disebabkan oleh faktor media ataupun bahan tanam yang sterilisasinya kurang sempurna. Sterilisasi yang kurang sempurna ini mengakibatkan tumbuhnya mikroba dalam media yang sangat kaya akan nutrisi.

Sterilisasi alat dan bahan menggunakan alkohol 70\%, karena alkohol merupakan denaturan protein yang memberikan sifat antimikrobial. Menurut Septimus (2019), Sterilisasi dapat dilakukan secara kimiawi dengan menggunakan alkohol 70\%. Alkohol bersifat antimikroba dengan mendenaturasi protein. Alkohol memiliki aktivitas bakterisidal terhadap sebagian besar bakteri gram positif dan gram negatif, termasuk organisme yang resisten berbagai obat. Konsentrasi alkohol antara 60\% dan 90\% merupakan konsentrasi paling efektif. Kebanyakan antiseptik tangan berbasis alkohol mengandung isopropanol atau etanol. Semakin banyak karbon penyusun dari alkohol tersebut, maka kemampuan untuk menghambat bakteri lebih besar.

Alkohol sebagai desinfektan akan membunuh bakteri melalui dua cara, yakni denaturasi protein dan pelarutan membran lemak. Menurut Susatyo (2016), pada saat terdapat alkohol di dalam lingkungan sel, maka kelarutan protein akan menurun karena alkohol dapat larut dalam air. Sedikit demi sedikit protein mengalami denaturasi. Akibat denaturasi, protein di dalam sel tidak dapat bekerja. Akibatnya, 
proses-proses penting di dalam sel menjadi terhambat. Hal ini juga sesuai dengan pendapat Mlcak et al. (2018) bahwa alkohol memiliki kemampuan untuk mendenaturasi protein terutama pada enzim dehydrogenase, dan umumnya bersifat antibakteri dengan merusak dinding sel.

\section{Panjang Tunas (cm)}

Salah satu parameter pertumbuhan kecambah kentang in vitro adalah panjang tunas. Rerata panjang tunas pada masing masing perlakuan (Gambar 4) menunjukkan bahwa perlakuan $\mathrm{K}_{15} \mathrm{~W}_{1}$ menyebabkan panjang tunas $(\mathrm{cm})$ tertinggi dan perlakuan $\mathrm{K}_{20} \mathrm{~W}_{1}$ menyebabkan panjang tunas $(\mathrm{cm})$ terrendah.

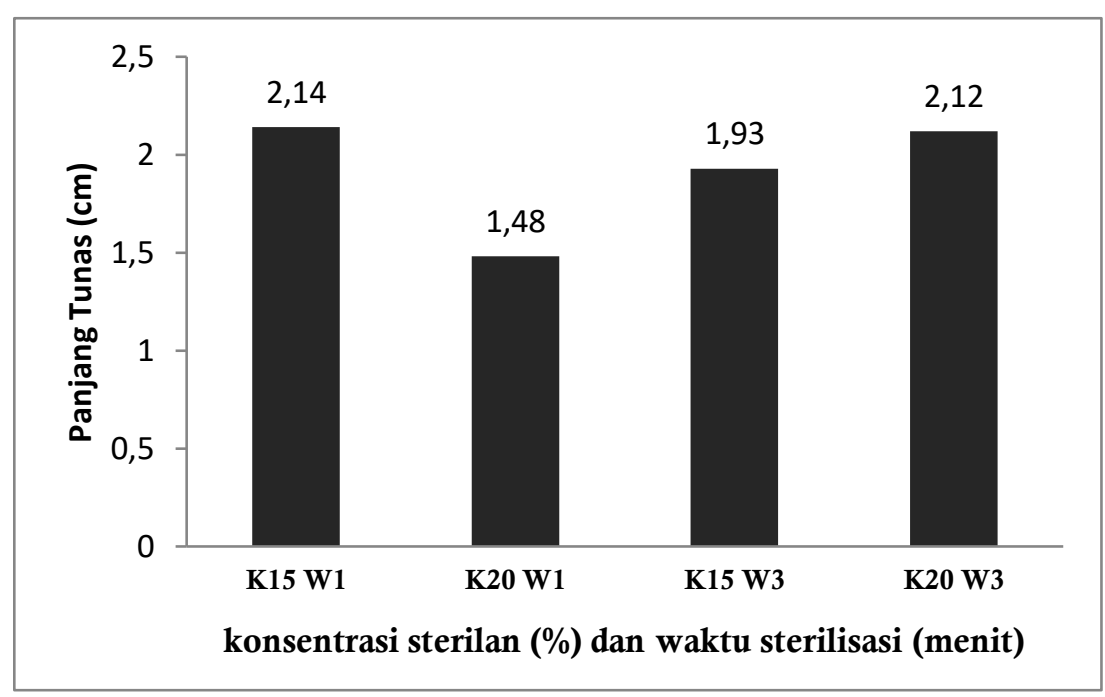

Gambar 4. Histogram rerata panjang tunas ( $\mathrm{cm}$ ) pada media MS dengan perlakuan konsentrasi sterilan (\%) dan waktu sterilisasi (menit) yang berbeda

Hasil analisis statistik menunjukkan bahwa pemberian konsentrasi $\mathrm{NaClO}$ baik $15 \%$ maupun $20 \%$ tidak memberikan hasil yang berbeda nyata. Kecambah yang tumbuh setelah perlakuan konsentrasi $\mathrm{NaClO} 15 \%$ dengan waktu sterilan 1 menit menunjukkan hasil yang terbaik yaitu dengan panjang tunas $2,14 \mathrm{~cm}$. Hal ini menunjukkan bahwa sterilan dengan konsentrasi 15\% tidak menghambat pertumbuhan kecambah. Kecambah dapat mengalami pemanjangan batang dengan baik. Batang yang mengalami pemanjangan disebabkan terjadinya proses pemanjangan sel dalam batang. Proses pemanjangan sel dipengaruhi oleh hormon auksin endogen yang akan meningkatkan pembelahan sel, pemanjangan sel, dan differensiasi sel. Menurut Novitasari et al. (2015), proses pemanjangan sel pada tanaman sangat dipengaruhi oleh hormon auksin baik itu yang disintesis oleh tanaman itu sendiri (endogen) maupun yang diberikan ke tanaman dalam bentuk zat pengatur tumbuh (eksogen).

Auksin yang diserap oleh jaringan tanaman akan mengaktifkan energi cadangan makanan dan meningkatkan pembelahan sel, pemanjangan sel, dan diferensiasi sel yang pada akhirnya membentuk proses pemanjangan tunas. Menurut Nurnasari dan Djumali (2012), hormon auksin berperan dalam proses pemanjangan sel dan terdapat pada titik tumbuh pucuk tumbuhan yaitu pada ujung akar dan ujung batang tumbuhan. Dalam kegiatan pembudidayaan tanaman biasanya digunakan hormon buatan (zat pengatur tumbuh) untuk mendukung pertumbuhan tanaman tersebut. Zat Pengatur Tumbuh (ZPT) 
dapat diartikan sebagai senyawa yang mempengaruhi proses fisiologi tanaman, pengaruhnya dapat mendorong dan menghambat proses fisiologi tanaman Proses pembentukan organ tanaman dibentuk karena adanya hormon auksin yang mampu meningkatkan aktivitas produksi enzim dan enzim merupakan hasil sintesis protein (Mayasari et al., 2012). Adapun hasil penelitian Leovici et al. (2014), auksin dapat mempengaruhi tinggi tanaman, jumlah daun, diameter batang, bobot segar akar, bobot sega tajuk, bobot segar total, bobot kering akar, bobot kering tajuk, bobot kering total, volume akar dan luas daun tebu.

\section{Jumlah daun}

Parameter pertumbuhan kecambah kentang in vitro yang juga diamati pada penelitian ini adalah jumlah daun (Gambar 5) karena pertumbuhan daun dipengaruhi oleh panjang batang. Semakin panjang batang maka jumlah daun akan semakin banyak karena daun tumbuh pada nodus yang terdapat pada batang. Hasil pada penelitian ini sesuai dengan teori tersebut karena jumlah daun terbanyak pada perlakuan $\mathrm{K}_{15} \mathrm{~W}_{1}$ dan batang kecambah terpanjang juga pada perlakuan $\mathrm{K}_{15} \mathrm{~W}_{1}$. Hasil analisis statistik menunjukkan bahwa pemberian konsentrasi $\mathrm{NaClO}$ baik $15 \%$ maupun $20 \%$ tidak memberikan hasil yang berbeda nyata terhadap jumlah daun.

Berdasarkan penelitian yang telah dilakukan pada perlakuan $\mathrm{K}_{15} \mathrm{~W}_{1}$ memberikan hasil yang paling baik, sedang pada perlakuan $\mathrm{K}_{20} \mathrm{~W}_{1}$ pertumbuhan daun agak terhambat. Jumlah daun pada perlakuan $\mathrm{K}_{20} \mathrm{~W}_{1}$ paling sedikit karena panjang batang pada perlakuan tersebut paling pendek. Hal ini diduga karena tingginya konsentrasi $\mathrm{NaClO}$ sehingga dapat mengganggu zat pengatur tumbuh yang terkandung di dalam biji dan kecambah. Hal ini sesuai dengan Hartati et al. (2016) yang menyatakan bahwa pembentukan daun selain dipengaruhi oleh auksin eksogen juga dipengaruhi oleh auksin endogen.

Daun merupakan organ yang banyak mengandung klorofil sehingga digunakan sebagai tempat berlangsungya fotosintesis. Fotosintesis yaitu proses biokimia pembentukan karbohidrat dari bahan anorganik yang dilakukan oleh tumbuhan. Menurut Hartati et al. (2016), jumlah daun pada pertumbuhan suatu tanaman memegang peranan yang sangat penting, hal ini berkaitan dengan kemampuan tanaman untuk melakukan proses fotosintesis dan berbagai metabolisme lainnya. Jumlah daun yang banyak akan menghasilkan fotosintat yang banyak pula sehingga pertumbuhan tanaman akan semakin baik. Menurut Sari et al. (2014), daun merupakan pusat terjadinya fotosintesis yang merupakan sumber bahan makanan bagi tanaman, sehingga semakin banyak daun maka diharapkan pertumbuhan tanaman akan semakin baik. Jumlah daun dipengaruhi oleh adanya penambahan zat pengatur tumbuh ke dalam media. Daun merupakan organ vegetatif dan pertumbuhannya dipengaruhi oleh kandungan nitrogen dalam media. Penggunaan media MS dengan kandungan nitrogen tinggi dapat memacu pertumbuhan organ vegetatif. 


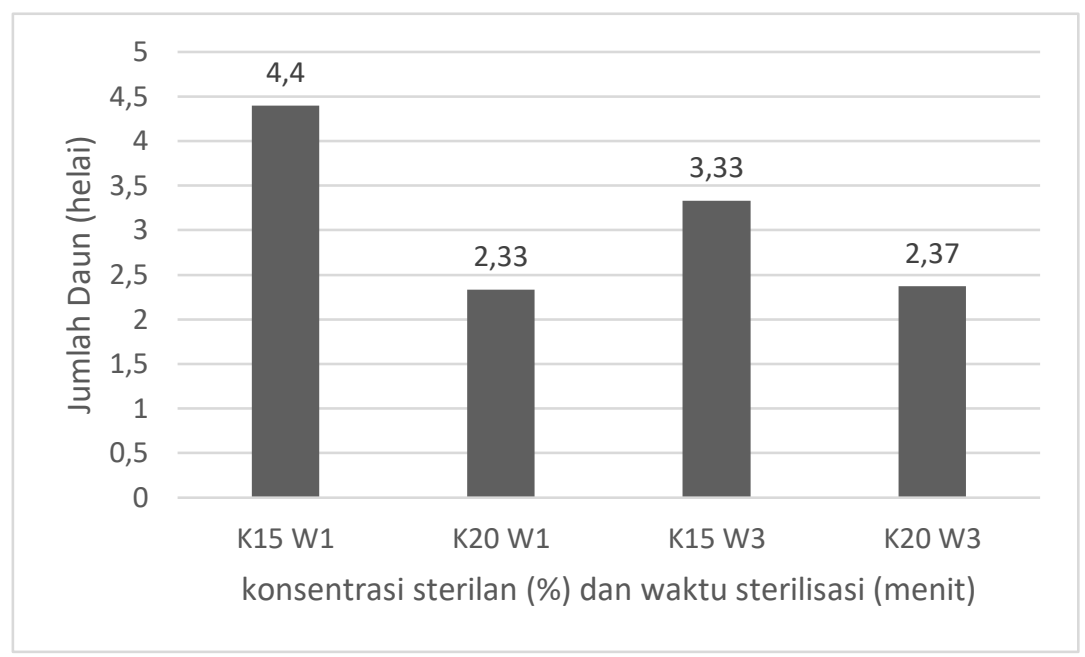

Gambar 5. Histogram rerata jumlah daun pada media MS dengan konsentrasi $\mathrm{NaClO}$ dan waktu perendaman yang berbeda

\section{Jumlah Akar}

Parameter pertumbuhan kecambah selain panjang tunas dan jumlah daun juga ditentukan oleh jumlah akar yang terbentuk pada kecambah. Rerata jumlah akar pada masing masing perlakuan (Gambar 6) menunjukkan bahwa perlakuan $\mathrm{K}_{15} \mathrm{~W}_{3}$ menunjukkan jumlah akar tertinggi dan $\mathrm{K}_{20} \mathrm{~W}_{3}$ menunjukkan jumlah akar paling rendah. Hasil analisis statistik menunjukkan bahwa pemberian konsentrasi $\mathrm{NaClO}$ baik $15 \%$ maupun $20 \%$ tidak memberikan hasil yang berbeda nyata terhadap jumlah akar. Konsentrasi sterilan 20\% menyebabkan pertumbuhan akar agak terhambat karena akar merupakan organ yang pertama kali muncul pada saat proses perkecambahan sehingga sangat dipengaruhi oleh konsentrasi sterilan yang digunakan untuk melakukan sterilisasi biji. Jumlah akar yang lebih rendah juga menyebabkan jumlah daun pada perlakuan konsentrasi sterilan 20\% lebih rendah dibandingkan 15\%.

Akar yang muncul pada kultur jaringan in vitro merupakan faktor penting karena akar dapat menyerap unsur hara sehingga dapat mendukung kelangsungan hidupnya. Hal ini sesuai dengan pendapat Hartati et al. (2016) bahwa jumlah akar tanaman mengindikasikan seberapa luas jangkauan tanaman dalam menyerap nutrisi, sehingga semakin banyak jumlah akar maka semakin luas pula jangkauan tanaman dan semakin banyak pula nutrisi yang dapat diserap. Selain itu, jumlah akar pada pertumbuhan secara kultur jaringan menunjukkan eksplan sehat dan mampu menyerap nutrisi dari media secara optimal. Jumlah akar yang terhambat yaitu pada $\mathrm{NaClO}$ dengan konsentrasi $20 \%(1 \mathrm{~cm})$ dipengaruhi karena sterilan menghambat kerja auksin endogen (IAA). Hal ini sesuai dengan pendapat Husniati (2010) yang menyatakan bahwa auksin memicu terjadinya pembelahan sel, sehingga diperlukan untuk pembentukan akar. Menurut Sari et al. (2014), adanya auksin endogen yang terdapat pada tanaman mengakibatkan terbentuknya akar. Kandungan hara yang tinggi pada media MS dan kadar sukrosa yang cukup mampu menyediakan energi yang cukup untuk pembentukan dan pemanjangan akar. 


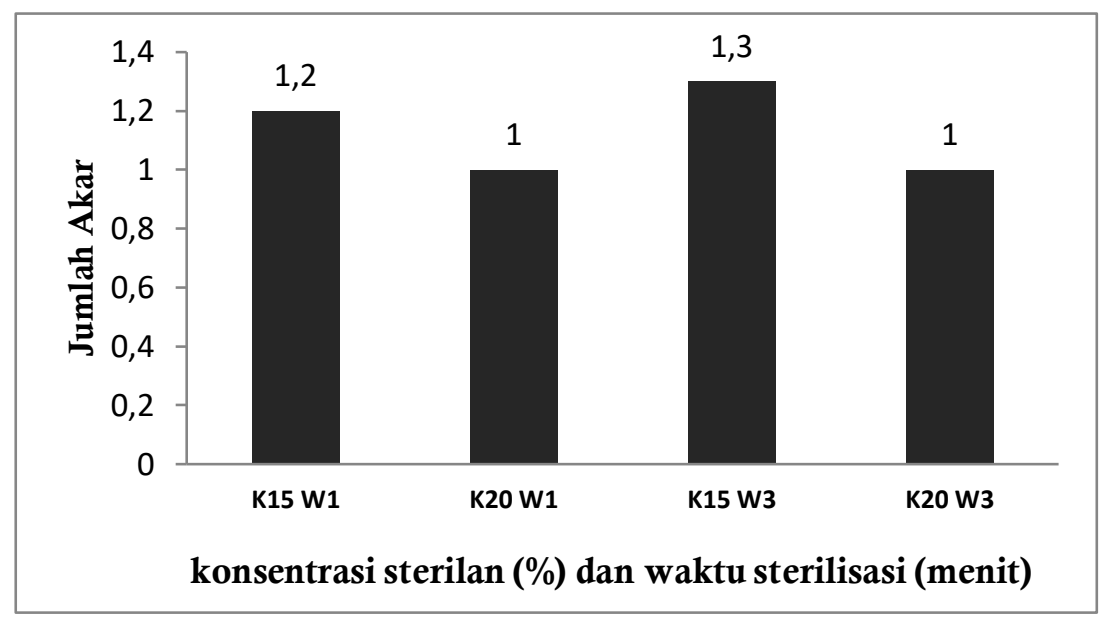

Gambar 6. Histogram rerata jumlah akar pada media MS dengan konsentrasi $\mathrm{NaClO}$ dan waktu perendaman yang berbeda

Hormon auksin merupakan senyawa kimia indole acetic acid (IAA) dihasilkan dari sekresi pada titik tumbuh yang terletak pada ujung tunas (terdiri atas batang dan daun), ujung akar, daun muda, bunga, buah, dan kambium. Menurut Wahidah dan Hasrul (2017), jika hormon auksin berada di ujung tunas, maka akan diangkut oleh jaringan berkas pembuluh (xilem dan floem) menuju tunas untuk tumbuh dan pemanjangan sel-sel jaringan batang.

\section{SIMPULAN}

Konsentrasi sterilan dan waktu sterilisasi tidak mempengaruhi waktu tumbuh kecambah dan pertumbuhan kecambah pada semua perlakuan tetapi konsentrasi sterilan yang lebih tinggi akan menyebabkan pertumbuhan akar dan daun pada kecambahan cenderung terhambat.

\section{UCAPAN TERIMA KASIH}

Peneliti mengucapkan terima kasih pada Universitas Diponegoro yang telah memberikan dana penelitian Riset Penelitian dan Pengembangan (RPP) dengan nomor kontrak 32951/UN7.P4.3/PP/2019 sehingga penelitian ini dapat terselenggara dengan baik.

\section{DAFTAR PUSTAKA}

Elfiani. (2013). Pengumbian in vitro kentang Granola (Solanum Tuberosum L.). Jurnal Dinamika Pertanian, 28(1), 33-38.

Haapasalo, M., Shen, Y., Qian, W., \& Gao, Y. (2010). Irrigation in endodontics. Dental Clinics North America Journal, 54(2), 291-312.

Hartati, S., Budiyono, A., \& Cahyono, O. (2016). Pengaruh NAA dan BAP terhadap pertumbuhan subkultur anggrek hasil persilangan Dendrobium biggibum dengan Dendrobium liniale. Journal of Sustainable Agriculture, 31(1), 33-37. 
Husniati, K. (2010). Pengaruh Media Tanam dan Konsentrasi Auksin terhadap Pertumbuhan Stek Basal Daun Mahkota Tanaman Nanas (Ananas comosus L. Merr) cv. Queen. Skripsi. Institut Pertanian Bogor.

Leovici, H., Kastono, D., \& Putra, E.T.S. (2014). Pengaruh macam dan konsentrasi bahan organik sumber zat pengatur tumbuh alami terhadap pertumbuhan awal tebu (Saccharum officinarum L.). Jurnal Vegetalika, 3(1), 22-34.

Mayasari, E., Budipramana, L.S., \& Rahayu, Y.S. (2012). Pengaruh pemberian filtrat bawang merah dengan berbagai konsentrasi dan Rootone-F terhadap pertumbuhan stek batang tanaman jambu biji (Psidium guava L.). Jurnal Biologi, 2(1), 99-103.

Mlcak, R.P., Suman, O.E., Sousse, L.E., \& Herndon, D.N. (2018). Respiratory Care, Total Burn Care, Fifth Edition. New York: Elsevier Inc: pp. 195-204.

Molla, M.M.H., Nasiruddin, K.M., Al-Amin, D.M., Khanam, M.A, \& Salam. (2011). Effect of growth regulators on direct regeneration of potato. International Conference on Environment and Industrial Innovation. 12, 205-210.

Nonogaki, H., George W. B., J. Derek B. (2010). Germination - still a mystery. Plant Science, 179: 574581.

Novitasari, B., Meiriani, \& Haryati. (2015). Pertumbuhan stek tanaman buah naga (Hylocereus costaricensis (Web.) Britton \& Rose) dengan pemberian kombinasi indole butyric acid (IBA) dan naphthalene acetic acid (NAA). Jurnal Agroekoteknologi, 4(1), 1735-1740.

Nurnasari, E., \& Djumali. (2012). Respon tanaman jarak pagar (Jatropa curcas L.) terhadap lima dosis zat pengatur tumbuh (ZPT) asam naftalen asetat (NAA). Agrovigor, 5(1), 26-33.

Pancaningtyas, S. \& Ismayadi, C. (2011). Sterilisasi ulang pada perbanyakan somatik embryogenesis kakao (Theobroma cacao L.) untuk penyelamatan embrio terkontaminasi. Pelita Perkebunan, 27(1), 110.

Sari, D.A., Slameto, \& Restanto, D.P. (2014). Induksi tunas kentang (Solanum tuberosum L.) menggunakan benzil amino purine (BAP). Berkala Ilmiah PERTANIAN, 10(10), 20-26.

Septimus, E.J. (2019). Nasal decolonization: What antimicrobials are most effective prior to surgery? American Journal of Infection Control, 47, 53-57.

Steinbrecher, T. \& Metzger, G. L. (2017). The biomechanics of seed germination. Journal of Experimental Botany, 68(4), 765-783.

Surahman, M. (2012). Pengaruh tingkat kemasakan buah, metode ekstraksi buah, metode pengeringan, jenis kemasan, dan lama penyimpanan pada mutu benih jarak pagar (Jatropha curcas). Jurnal Ilmu Pertanian Indonesia, 18(2), 73-78.

Susatyo, J.H. (2016). Perbedaan pengaruh pengolesan dan perendaman alkohol $70 \%$ terhadap penurunan angka hitung kuman pada alat kedokteran gigi. Jurnal Vokasi Kesehatan, 2(2):,160-164.

Wahidah, B.F. \& Hasrul. (2017). Pengaruh pemberian zat pengatur tumbuh Indole Acetic Acid (IAA) terhadap pertumbuhan tanaman pisang sayang (Musa paradisiaca L. var. Sayang) secara in vitro. Jurnal Teknosains, 11(1), 27-41.

Webster, R.E., Waterworth, W.M., Stuppy, W., West, C.E., Ennos, R., Bray, C.M., \& Pritchard, H.W. (2016). Biomechanical, biochemical, and morphological mechanisms of heat shock-mediated germination in Carica papaya L. seed. Journal of Experimental Botany (in press).

Wiguna, G. (2013). Perbaikan viabilitas dan kualitas fisik benih tomat melalui pengaturan lama fermentasi dan penggunaan $\mathrm{NaClO}$ pada saat pencucian benih. MEDIAGRO, 2(2), 68-76.

Wolny, E., Betekhtin, A., Rojek, M., Braszewska-Zalewska, A., Lusinska, J., \& Hasterok, R. (2018). Germination and the early stages of seedling development in Brachypodium distachyon. International Journal of Molecular Sciences, 19(10), 2916-2923.

Yan, D., Duermeyer, L., Leoveanu, C., \& Nambara, E. (2014). The functions of the endosperm during seed germination. Plant and Cell Physiology, 55, 1521-1533.

Yuniarti, N., Megawati., \& Budi, L. (2013). Pengaruh metode ekstraksi dan ukuran benih terhadap mutu fisik-fisiologis benih Acacia crassicarpa. Jurnal Penelitian Hutan Tanaman, 10(3), 129-137. 